\title{
A Bio-Social Review to Mitigate the Punishment of Unwanted Acts
}

\author{
Armin Alimardani ${ }^{1, *}$, Ali M. Ardekani ${ }^{2}$ and Leila R. Astany ${ }^{3}$ \\ ${ }^{1}$ Department of Criminal Law and Criminology, Damghan Branch, Islamic Azad University, Damghan, Iran \\ ${ }^{2}$ The National Institute of Genetic Engineering and Biotechnology (NIGEB), Tehran, Iran \\ ${ }^{3}$ Department of Criminal Law and Criminology, Science and Research Branch, Islamic Azad University, \\ Tehran, Iran
}

\begin{abstract}
Commitment of crime and exhibition of antisocial behavior have been considered as negative acts from early times of human civilization. Recent scientific advances have identified contributions of biological and sociological (environmental factors) factors in forming a maladaptive behavior. Generally, it is accepted by many scholars that punishing a wrongdoer, who has committed a crime owing to genetic predispositions and environmental elements, is not effective and forms of treatments should be replaced to avoid repeating a crime. Moreover, by identifying genetic deficiencies in an individual, an antisocial behavior could be potentially predicted and prevented before it comes to pass. On a whole, genetic and environmental factors, sometimes solely and some other times collaboratively, lead a person to act against society norms. In summary, this body of literature offers examples that explain factors which contribute to committing crimes and approaches which inhibit antisocial behavior. With regard to these aims, we suggest that punishment of criminals who are predisposed genetically in the same manner as other delinquencies is not justifiable and a reduction of punishment should be applied to such individuals. Moreover, by eliminating each of negative elements which contribute to antisocial behavior or crime, we can be more certain that the offender will not repeat antisocial acts after being released.
\end{abstract}

Keywords: Crime, antisocial behavior, punishment, genetics, sociology.

\section{INTRODUCTION}

Criminology is a system of law, which addresses the analysis of criminal behavior. This field is considered as a multi-disciplinary field including psychology, social sciences and neuroscience (Bosse, Gerritsen, \& Treur, 2011). It has been a while that genetics has affected this subdivision of law and it is found by genetic researches that genes not only impact on our behavior, but also they sometimes play a prominent role in our controllability (DeLisi, 2012). By considering this issue, it could be concluded that from time to time, free will is impaired and consequently this can change judgment on verdict. It seems that like famous Stephen Mobley's case in 1994 (Farisco \& Petrini, 2012), several lawyers asked for genetic examination. In this respect, there is a controversy among experts as how to adjust punishments by taking into account the influences of genes and environment, which made this issue a double-edge sword (Farahany \& Coleman, 2006). On the one hand, some scientists believe that it is logical to decrease punishment of the accused because of lack of free will (Alimardani \& Abbas Zade, 2014). On the other hand, other law experts think that when culprit is released, the crime may be repeated because of loss of controlling behavior and therefore the punishment should be increased. According to criminal

*Address correspondence to this author at the Department of Criminal Law and Criminology, Damghan Branch, Islamic Azad University, Damghan, Iran; Tel: +98-912-618-4497; Fax: +98-2188146134;

E-mail: armin.alimardany@gmail.com responsibility, punishment for an innocent individual is dishonorable, and could not properly fulfill the moral expressive goals of the criminal law (Fine \& Kennett, 2004; Alimardani, 2012). Thus, in this article, two main reasons to decrease sanctions are explained. Firstly, via a bio-social perspective, it is discussed that many acts are not under control of individuals. Moreover, some approaches to treat individuals with biological and environmental problems as well as prediction and inhibition of their antisocial acts are explained.

\section{PUNISHMENT OR TREATMENT?}

It is believed that if society is not satisfied with a person's act, it should be decided by the society to make a decision about this unlawful behavior, whether it should be punishment, or medical remediation or something else (Hallett, 2007). Regarding this, how can we punish a wrongdoer who had a partial decisionmaking process or self-control? We just can punish a person who acts purposefully, consciously and logically. This reveals why children and patients with mental disorders cannot be responsible (Morse, 2011). Consequently, we should mitigate those culprits responsibility, which genetically or mentally predisposed to be aggressive or antisocial. However, some scholars believe that if we release offenders under these circumstances, they may repeat their unlawful acts because they cannot control their behaviors as we do and it is better to aggravate their penalty rather than reducing (Fine \& Kennett, 2004). 
Utilitarian theories of punishment- which basically stress on the beneficial outcomes for human beings and society- aim to reform an individual. While reforming a person will prohibit next antisocial acts (Fine \& Kennett, 2004), we know that punishment is not an appropriate way of reforming. In order to rehabilitate a delinquent, we should treat that person via methods suitable to human psychosocial needs.

\section{BIO-SOCIAL FACTORS OF ANTISOCIAL BEHAVIOR}

In this section, we are going to discuss how biosocial elements can lead a person to exhibit antisocial behavior. However, it is noteworthy that through this perspective, prevention (such as parental monitoring) and prediction (such as lead exposure) of unlawful acts is possible. It is critical to prevent maladaptive behaviors in case of recidivism. Thus, wherever it is relevant, it is discussed how we can predict and prevent antisocial behavior.

\section{GENETIC PREDISPOSITIONS}

The genetic $X$ environment interaction is well discussed for many years and to some extent, we can say it is over (Turkheimer, 2000). Genes and environment both have role in meditating antisocial behavior. Nonetheless, there are mounting evidences that genetic and biological elements could have more influence on shaping maladaptive character (Barnes \& Boutwell, 2012; Beaver, Wright, DeLisi, \& Vaughn, 2008; Turner, Livecchi, Beaver, \& Booth, 2011; Christopher J. Ferguson \& Beaver, 2009; Vaughn, DeLisi, Beaver, \& Wright, 2009). For example, scientific reports indicate that some aggressive traits are strongly linked to particular genes (Susman, 2006).

In this section, through some examples it can be easily observed that genetic elements can play a major role in shaping a behavior.

\section{HUNTINGTON DISEASE}

Sometimes, a genetic factor alone can cause a health effect: several variations in the Huntington gene lead to Huntington's disease (HD) which noticeably affects sick person's behavior (Kaye, 2006). HD is known to arise from the effects of a single altered gene (Alper, 1998). As the disease progresses uncoordinatedly and jerky body movements become more apparent, a decline in mental abilities as well as behavioral and psychiatric problems occurs. Physical abilities are gradually impeded until coordinated movement becomes very difficult. Mental abilities generally fall into dementia (Montoya, Price, Menear, \& Lepage, 2006) which include hallucinations, antisocial behaviors and paranoia (National Center for Microscopy and Imaging Research, 2011). HD could be predicted by genetic test (Myers, 2004).

\section{MAOA Gene}

MAOA is a gene, which is located on the $X$ chromosome. MAOA's function is to code for monoamine oxidase A enzyme (Eme, 2013). Lower levels of MAOA could relate to higher aggression only if the individual in his childhood experienced maltreatment (Bjorklund, 2006). MAOA is one of the most valid reasons that represent gene $X$ environment interactions. One study on 442 boys in New Zealand has indicated that antisocial behavior in males can derive from dysfunction of MAOA gene plus early childhood abuse. In this study maltreatment included lack of primary care giver, rough strictness, physical and sexual abuse and so on (Susman, 2006; Widom \& Brzustowicz, 2006). Some scholars believe that criminal and antisocial behaviors can increase more than nine times if this environmental situation and gene deficiency occur together (Morse, 2011).

\section{DOPAMINE}

Dopamine has an important role in the body and brain of animals. In brain dopamine plays the role of a neurotransmitter. Variety of dopamine system in the brain is recognized. One of the significant dopamine systems in the brain is reward-motivation behavior. For instance, many drugs like cocaine, amphetamine, and methamphetamine impact on drug users by increasing the influence of dopamine. Other brain dopamine systems are engaged in motor control and in regulating the release of a number of important hormones (Wikipedia, 2013). Research findings indicate that dopaminergic genes such as DRD2 and DRD4 are related to violence and psychopathic personality trait (Chichinadze, Chichinadze, \& Lazarashvili, 2011; Christopher J. Ferguson \& Beaver, 2009; Wu \& Barnes, 2013). Moreover, DAT1 gene located on chromosome five and codes for production of the dopamine transporter protein can be repeated between three to eleven times. Scientists have identified DAT1 ten repeat $(10 R)$ allele as "risk allele", which could enhance sensation seeking, violence, aggression and antisocial behavior (Christopher J. Ferguson \& Beaver, 2009; Schilling, Walsh, \& Yun, 2011; Vaughn et al., 2009). 


\section{Testosterone}

Salivary testosterone has positive correlation with CAG length variation in the AR (Androgen receptor) gene (Manuck, et al., 2010). Testosterone (T) is the main male sex hormone, and it is associated with aggressive behavior. However, it does not mean that higher level of testosterone always result in more aggressive and antisocial behavior. It is known that boys at puberty receive a dramatic amount of testosterone, nevertheless, a definite violence and aggression does not emerge. However, in sample of wrongdoers and young adults this connection was considerably pronounced. (Humphreys \& Campbell, 2011). These findings paint a complex picture of relation between $T$ level and aggression. On a whole, some researchers believe that there is a higher positive correlation between $\mathrm{T}$ level and dominance over $\mathrm{T}$ level and aggression. It is noteworthy that in many fields and events, dominance is established when aggression manifests. Aggression frequently acts as an incidence in developing hierarchy shaping (Chichinadze et al., 2011). In other words, in order to achieve a better social position and dominance over other population, aggression could be a tool.

Taking everything into account, we can obviously notice that how gene predispositions affect an individual personality and especially antisocial behaviors.

\section{ENVIRONMENTAL FACTORS}

Genetic predispositions and hormones, which results in aggressive behaviors could be moderated by the environment (LaPrairie, Schechter, Robinson, \& Brennan, 2011). Genetic predisposition for antisocial behaviors is considered a risk factor and it would guide the individual acts toward a specific result. But this risk factor is prerequisite to the outcome. Thus, a measured environment could cause an alteration to another pathway (gene predisposition) and result in an appropriate outcome (Blazei, lacono, \& Krueger, 2006). On the other hand, some situations could intensify the effect of an adverse gene. Maternal depression for example, could increase the possibility of behavioral disorders in children (Susman, 2006). Findings show that hormone levels would change in response to the environment. In other words, some hormone levels such as Testosterone vary by social experiences and result in different behavior (Gleason et al., 2009). In brief, bio-social studies explain that necessary psychological and biological development passages happen during pre-teens and teenage years. If these psychological and biological factors are expressed by good social experiences, negative biological power would be eliminated and well maturation of brain circuitry related to impulse-control system develops and empathy will take place. Conversely, if these biological and psychological factors are expressed through adverse social experiences, it can result in intensifying antisocial outcomes (Yildirim \& Derksen, 2012)

Some factors such as sex and age cannot be changed at each stage of life. Therefore, the environment should be modified to some extent for a satisfactory result. Thus, we argue these two factors first and then address two main environmental factors.

\section{Stable Factors}

\section{Gender}

One of the most significant predictors of unsocial behavior is gender (Morgado \& Vale-Dias, 2013). Behavioral differences because of sex diversity could derive from specific hormones, neurotransmitters, brain structure and genes. Gender differences in brain structure, because of exposure to androgens in specific span of time (pre- and postnatal brain maturation) set up the brain to yield a range of gender distinction in brain including distribution of steroid receptors, and neuropeptide gene expressions leading to change of behavior. (Shepard, Michopoulos, Toufexis, \& Wilson, 2009). Many researchers confirm that physical contention and aggressive behavior is more common among males than females, even genetic impact is reported to be somewhat more robust in men than women (Victoroff, 2009; Bezdjian, Baker, \& Tuvblad, 2011). In addition, even girls with maladaptive behaviors in comparison with boys have less inclination toward intensive violent acts (Morgado \& Vale-Dias, 2013).

\section{Age}

Generally, early ages of a human being are more critical than other ages because of flexibility of brain. In fetal and early childhood, brain system is more sensitive, which makes the environmental circumstances more important (Susman, 2006). Age is one of the main factors for predicting antisocial behavior such as early onset of antisocial behavior. Early antisocial behavior could increase the possibility of delinquency in coming years like combats at eighteen, assault of 
partners and forceful crimes at the age of thirty-two. (Walker, Bowen, \& Brown, 2013). Although genetic effects seem to be critical for the entire lifetime, however, it is reported that genetics' effects to be strongest among young individuals (Bezdjian et al., 2011).

It is worth to note that there is also a body of literature supporting the negative correlation between age and crime. Some scholars believe that causes of this phenomenon could include alternations of testosterone, serotonin, dopamine and norepinephrine through passages of time. The relationship between levels of serotonin in brain and aggression is proven and lower level of serotonin in the brain is correlated with more aggressive behavior. But, serotonin's level goes up by growing up. Seemingly, norepinephrine and dopamine are related to aggression and they decline by aging (Walker et al., 2013). Moreover, testosterone could be a regulator which has correlation with age. Prior to puberty and later in life, testosterone levels go down (Book et al., 2001). Likewise, Age-crime graph, according to the United States Federal Bureau of Investigation, shows committing crime peaks between 15 to 20 and declines afterwards. (Blonigen, 2010).

It can be concluded that, how important it is to take the accused gender and age into consideration during the criminal procedure in order to reach an appropriate punishment and treatment.

\section{MAIN ELEMENTS}

In general, three main socialization areas can be distinguished: family, school and peer groups (Garnefski \& Okma, 1996). We also added mass media owing to the fact that nowadays media play an important role in socializing individuals.

\section{FAMILY}

Undoubtedly, family is an important part in forming a sociable child. Children experience their first social behaviors through their family (Morgado \& Vale-Dias, 2013). Families have many shapes such as biological or adaptive parents, one biological and one stepparent, a single parent who is divorced and so on. What is important here is not a specific kind of supervisor; actually, the relationship between a child and her caretaker dramatically influences forming a personality (Henggeler, Schoenwald, Borduin, Rowland, \& Cunningham, 2009). Parents' interaction with children could be warm or cold. Warm caretaking could end in children with empathetic traits and sociable interaction and children who passed their childhood with rejection would be deprived from learning trust and empathic reflection (Henggeler, Schoenwald, Borduin, Rowland, \& Cunningham, 1998).

\section{MATERNAL CARE}

It is well known that how much early adverse experiences have a significant linger influence on later behaviors. By considering this fact, and considering that most of early interactions of newborn children up to a specific age is with their mothers, make it critical to flash the spotlight on maternal care (Shepard et al., 2009). With regard to the fact that mothers provide $50 \%$ of their offspring genes, this connection in first years of childhood, make inheritance effect to surpass $50 \%$. Specifically, in mammals, mothers are the greatest environmental factor, which exist around the baby animal. As big-brained animals divulge more plasticity behavior, this feature might be more prominent (Bjorklund, 2006). Thus, if a mother creates a warm and positive environment, that child might act socially within the next years. On the contrary, if the child experience a cold and negative environment, undesirable results is more possible to be observed.

\section{PRENATAL ENVIRONMENT}

Maternal care during prenatal period is critical. Prenatal environment can have two aspects. While adverse prenatal environment could intensify maladaptive behaviors, it could mediate for inhibiting further aggressive and violent behavior (Liu, 2011). For instance, exposure to chemical environment during pregnancy could affect gene transcription, which can result in epigenetic disorders or due to alcohol and tobacco exposure neuropsychological impairment will happen. Moreover, intrauterine growth retardation can cause ADHD (attention deficit hyperactivity disorder), addiction, and schizophrenia spectrum disorder (Vucetic et al., 2010). One of the most important issues researches have focused on during pregnancy is smoking. Many scholars believe that smoking during pregnancy can affect latter behaviors of fetus such as lowering self-control, conduct disorder and violation (Turner et al., 2011; Liu, 2011).

A research has suggested that those mothers who smoke 20 cigarettes or more per day during their gestation period may increase the adult violent offending by two times. In addition, maternal stress during pregnancy could end in harmful embryo's 
shaping organ systems, like brain. Likewise, prenatal stress which can cause by exposure to cocaine during pregnancy period can yield antisocial behaviors among young children (Liu, 2011).

\section{MALTREATMENT}

World Health Organization (WHO) defines maltreatment in this way: "Child maltreatment, which is sometimes referred to as child abuse and neglect, includes all forms of physical and emotional illtreatment, sexual abuse, neglect, and exploitation that results in actual or potential harm to the child's health, development or dignity. Within this broad definition, five subtypes can be distinguished - physical abuse; sexual abuse; neglect and negligent treatment; emotional abuse; and exploitation" (WHO, N.d.). Studies have provided convincing evidence of association between maltreatment and antisocial behaviors. Researchers found that children who have experienced maltreatment are at risk of addiction, behavioral disorders in adolescence and later adulthood, about five-fold-likelihood to be arrested for juvenile delinquency, two-fold possible of arrest for criminal behavior in adulthood. Some problems, which can result in aggressive and violent behaviors, could arise from maltreatment by causing drug use and psychiatric disorders (Liu, 2011). In addition, conduct problem for adolescents who had genetic predispositions were twelve times more effective in comparison with those who did not have genetic risks (DeLisi et al., 2008). An interesting study examined a sample of violent behaviors and concluded that majority of extreme psychopaths ${ }^{1}$ were in severe relational trauma in their childhood and showed indicators of disorganized attachment (Schimmenti et al, 2014). A study of sexual assaulters and rapists demonstrated that a major part of them was sexually abused before (Shepard et al., 2009). Last finding is a warning for criminal judicial system to be concerned about victims of sexual abuse too. These victims are inclining to commit similar crimes in future.

\section{MONITORING}

Hundreds of studies show that the youth are more intent to commit crime in two circumstances: First, if parents could not develop emotional bond and heartfelt

${ }^{1}$ Psychopathy is a well-known personality disorder in the psychological and criminological fields. relationship with them. Second, if parents do not monitor them (Barber, 2008).

Many other studying suggest that parental control would prevent further antisocial behaviors and develop children's self-control (Beaver, Wright, \& Maume, 2008; Turner et al., 2011). Thus, preventing children from taking the wrong path by supervising their behavior could inhibit many maladaptive behaviors in adult years of their lives.

\section{LONE PARENTING, NUMBER OF OFFSPRING AND POVERTY}

Single parenting, number of children and poverty in a family are considered risk factors (Barber, 2008, 2009). Offspring of divorced parents are more susceptible to manifest antisocial behaviors, violent crimes and find difficulty with law (Barber, 2009). One of convincing reason of this matter is about parental investment. It is known that if fewer parents monitor their children, the more they are disposed for antisocial behavior. When parents get divorce or one of them dies, monitoring will be reduced. They cannot pay attention to their children as they did before (Church, Jaggers, \& Taylor, 2012). Furthermore, this scenario could be in number of children. The more infants in a family exist, the less time for each of them could be spent, especially for emotional support. Lack of emotional support has been shown to have a critical relation with maladaptive behavior and violence (Barber, 2008). Regarding this issue, another study indicated that lone parenting and consequently low supervision as well as child abuse for children under 16 could result in problem with peers and bullying victimization in later adolescence and also it could result in subsequent reactive aggression and conduct disorder in young adulthood (Bifulco, Schimmenti, Jacobs, Bunn and Rusu, 2014). Poverty is considered as an adverse environment and is related to antisocial and violent behaviors (DeLisi et al., 2008; Christopher J Ferguson \& Kilburn, 2009; LaPrairie et al., 2011; Miller, 2013; Morse \& Hoffman, 2007; Umukoro, Aladeokin, \& Eduviere, 2013; Walsh, Glab, \& Haakenson, 2004). In general, poverty makes a child to be in more psychological stress which could increase stress hormones and result in harmful consequences in brain growth. Children of needy families have more emotional problems and difficulties in the area of physical punishment and so on. Consequences of these issues comprise elevation in criminal acts, culpability, decline of income ability and so forth (Barber, 2008). 


\section{School}

School is a place where children encounter with a wider range and different rank of society and this is in contrast to the years prior to schooling where children connect to a restricted range of society. They learn how to contact other race, sex, different people as well as inflexible rules, timetables, and norms (Macions \& Plummer, 1997). Undoubtedly, the purpose of school is to develop pro-social behaviors. In the same way, school has some kind of side-effects and could cause conduct problems. Social learning theory elaborates on this issue by pointing out that pupils may learn, copy and approve antisocial behaviors during interaction with other students (Beaver, Wright, \& Maume, 2008). Findings show that children who are studying in classes with more unruly students are more likely to decrease levels of self-control (Beaver, Wright, \& Maume, 2008). Perhaps remarkably, boys manifest aggressive, criminal as well as addiction-risk acts in association with school problems, whereas girls indicate these kinds of problems in connection with home problems (Garnefski \& Okma, 1996). Several school-base crime prevention programs have provided evidence to point out biological predispositions for these behavioral activities. For instance, Conrod, Castellanos-Ryan, and Strang (2010) prepared a program for high impulsive and sensation seeker students. After two years of problem-solving education and cognitive behavioral therapy of test group in comparison with control group, it concluded that intervention group had less drug use and less inclination to new drugs (Conrod et al., 2010; Rocque, Welsh, \& Raine, 2012).

\section{Peer Groups}

Peer groups can shape by school, neighborhood and university friends and elsewhere (Macions \& Plummer, 1997). Regarding peer group, students who are friend with rebel and troublemakers at school, have more problems with following pro-social manners (Beaver, Wright, \& Maume, 2008). Considering peer group's effect on adolescents, a study on risk-taking behavior in a group of 16 to 18 year olds $(n=269)$ in Israel indicated that males are impressively influenced by attitudes of peer group. However, results indicated that females are significantly affected by their parents bond. Another study reported that young male individuals behavior are influenced in association with friends who manifest unsocial behaviors; while females are more in relationship with friends who have social behaviors (This phenomenon indicates another difference in gender). Generally, adolescents who manifest violent behaviors usually have the main part of their friends associated with antisocial behaviors but adolescents who show less aggressive behavior usually have friends with more social acts. (Baxendale, Cross, \& Johnston, 2012).

On a whole, peer groups could have a significant impact on growing and predicting conduct disorder. In addition, many criminal acts occur in form of peer groups. (Garnefski \& Okma, 1996; Henggeler et al., 2009). People usualy have more courage when they perform an activity in a group. Thus, peer groups can help adolescents to commit crimes more easily.

\section{Mass Media, Internet and Computer Games}

Nowadays, reading newspapers, magazines and specially watching TV are great matters. Children spend a lot of time playing video games while more than $85 \%$ of these games involve violence and about half of them have serious violent actions (Carnagey, Anderson, \& Bushman, 2007).

If these activities have side effects, they can influence wide range of young people. Not only interaction with violence of low empathy can result in motivation for violent behaviors, but also it could desensitize to violence. Desensitization to violence is usually the outcome of interaction with violent media and could increase aggressive behavior. Some scholars believe that associating in excess of need in video games can prevent children from developing social process including failure of developing relative brain areas that mediate moral and social norms, which hardly form without communicating in real society (Funk, 2005).

\section{Other Elements}

\section{Neighborhood}

The link between neighborhood and antisocial behaviors is related to this fact that the more a family be in exposure of negative neighborhood environment, the more likely the family will experience and become familiar with negative acts and stress (Church et al., 2012).

Desensitization to violence, which can decrease sensitivity of physiological reactivity (Carnagey et al., 2007), may happen because of interaction with aggressive behavior in inappropriate neighborhood. This means exposure to violence could result in 
development and manifestation of psychopathic traits. In other words, being in a place which violent behavior is common may cause desensitization to violence and increase antisocial features (Schraft, Kosson and McBride, 2013).

\section{MALNOURISHMENT AND DIET}

Surprisingly, nutrition is more important than general belief. Nutrition during pregnancy and early childhood significantly shape maturation of brain. Lack of macronutrients (like protein), micronutrients (like zinc and iron), etc., could disrupt brain process and result in predisposition to behavior problems. For instance, male child maladaptive behavior could grow by 2.5 times in adulthood if during first and second trimester of pregnancy, mother experience intensive malnourishment. In addition, another finding shows that at age three, insufficient protein, zinc, iron, and vitamin B could increase behavior disorder, aggression and/or hyperactivity at ages eight, eleven and seventeen (Liu, 2011).

Diet could influence anti-social behaviors. It is confirmed by three well-designed studies that vitamin or mineral supplementation decrease maladaptive behavior. Moreover, studies suggest relation between low blood glucose and aggression. If glucose levels become lower than a specific amount, brain function might disrupt and cause confusion, amnesia, blurred vision, bizarre behavior and as some scholars suggest violent crimes (Benton, 2007).

\section{AIR POLLUTION}

Air pollution is an environmental factor that could anticipate criminal behavior in later years. Scholars suggest that lead exposure is correlated to crime trend. Scientists suggest that lead exposure could increase aggressive and criminal behavior during childhood up to 2.7 times and can affect adult's behavior as well. Moreover, exposure to lead has a positive trend since expended lead could store as dust in soil and it could be as additional source of lead exposure. Likewise, lead exposure during prenatal and postnatal is correlating with greater extent of criminal arrests in early adulthood (Liu, 2011). Also, it is argued by some scientists that lead exposure is not only associated with violent and repeating delinquency, but also it is connecting to property crime and burglary too (Nevin, 2007).

Perhaps remarkably, hair manganese levels are linked to conduct disorder in infants who were exposed to drinking water containing the element. Manganese effect on behavioral disorders may function through changing levels of dopamine and serotonin (Haynes et al., 2011). As it is mentioned before, serotonin's levels in brain are associated with aggressive and antisocial behaviors.

Interestingly, tobacco smoke and by-products of tobacco are considered paramount indoor pollutants. On average, about $40 \%$ of children, $35 \%$ of women, and $33 \%$ of men are frequently in exposure of passive smoking and could result in ADHD and maladaptive acts (Pagani, 2013).

In the first section, we observed how sex could make a difference in behavior. On a whole, males are at more risk to manifest antisocial behaviors than females. Moreover, regarding the age, we understood that onset of antisocial behaviors could play a significant role in maladaptive behaviors. In addition, aging could have a positive correlation with accepted norms of behavior. Finally, we observed that how environmental factors can cause antisocial behavior and lead a person to commit crimes.

Consequently, we can understand that some delinquents are not acting completely freely and they are behaving owing to negative environmental elements; whether it has root in their past or present.

\section{MIXTURE OF BIO-SOCIAL DEFICIENCY}

Manifestation of a disorder like violence to some extent is the mixture of a person propensity and a particular situation with a promoting provocation. In other words, occurrence of an unsocial act is often highly depended on situations and not presence or absence of antisocial character. This situation could be frustration, conflict or an experience such as threat with a cognitive state (like cognitive deficit) and affective state (like anger) which result in aggressive behavior. Facilitating factors such as peer-group support, high level of testosterone as well as inhibiting factors such as morality, empathy and fear of punishment varies the measure and possibility of violent act. For instance, high-risk alleles often need at least low stimuli to make aggression take place. Consequence of wrong act would be greater if a gun is in access of wrongdoer. Conversely, if wrongdoers were under medication, the consequence would reduce (Steinert \& Whittington, 2013). Generally, we have already known that it is impossible to eliminate all risk factors, but reducing some facilitating elements and adding inhibitory factors 
like what was mentioned above could reduce the likelihood of an antisocial behavior dramatically.

Bearing what was noted above in mind, in the next section, it is argued that we can treat criminals in different ways.

\section{TREATMENT}

Treatment is important due to possibility of recidivism. Treatment can take place after commitment of crime or before anything happen so as to prevent delinquency. Criminals who have some kind of disorders are more likely to commit crimes than others. Thus, before releasing these delinquents, we should be sure of their mental health. Here are just some possible examples of treatment out of hundreds of approaches.

\section{PHARMACY}

Biochemical therapy is an approach to mediate neurotransmitter precursors and other critical body chemicals which are imbalanced (such as proteins) due to problem alleles or adventitious abnormalities. Pfeiffer Treatment Center (PTC) of Warrenville, IL, has gathered a great database of biochemical information during ten years research on more than 8000 behaviordisorder patients. Results showed dramatic chemical abnormalities among behavior-disorder patients in comparison with general population. Scholars have suggested that biochemistry imbalance has a significant impact on human acts. Regarding crimes and antisocial behavior, maybe body chemistry abnormalities ought to be well adjusted in the first years of childhood to result in a successful inhibition (Baker, 2004; Walsh et al., 2004). Pharmacological means are known to regulate antisocial behaviors. For instance, fluoxetine (Rrozac) resulted in sustained decrease in irritability and aggression (Siegel \& Douard, 2011).

Generally, regulating chemical imbalances could be one of the most important methods of inhibiting antisocial behavior. It is well-known that many of genetic and environmental defeciencies are causing chemical imbalances. Thus, as it has just been mentioned, this problem could be solved through Pharmacological approaches.

\section{EDUCATION AND PSYCHOTHERAPY}

Parents and teachers training could be efficient indirect methods in order to reduce risk factors in an infant's environment. Inappropriate parenting skills increase the probability of learning antisocial behaviors by children. This idea is developed by social control theory which presumes: Children learn behavior through individuals supervising behavior. Likewise, infants could be violent if their observers act aggressively (Church et al., 2012). Inhibiting neuropsychological or cognitive deficits in parallel with other risk factors are aims of parenting programs. For example, imagine asking mothers to stop smoking or ingesting narcotics in prenatal period or reducing second hand smoking, like smoking outside, avoiding smoking in the car, and smoking from afar of children, could be effective in order to decline neuropsychological deficits (Pagani, 2013; Rocque et al., 2012). Teacher training could be carried out with standardized classroom management techniques. For example, organizing physical environment to decrease possibility of struggles, setting clear rules, socializing pupils to act in a positive behavior and so on (Klevens et al., 2009; Poduska et al., 2008).

Perry Preschool is one of the most well-known preschool intellectual enrichment programs. Results of this program showed dramatic fewer arrests because of violent crimes, property crimes, drug crimes, significant higher levels of schooling, higher annual earnings and so on. Interestingly, several school-based crime prevention programs are organized for children whose biological risk factors are recognized (Rocque et al., 2012)

Some scholars discuss about actions that are not to some extent chosen freely. For example, if genetically or environmentally, levels of serotonin decrease, individual would be more aggressive and violent. Libet (1985) believes that even if our consciousness did not or could not start a behavior, that person might be able to train a "conscious veto" of the behavior. In other words, decisions can be predicted up to ten before a person becomes aware about the decision. Thus, if training would have an effect on initial decisions and result in more adaptive behaviors, in these situations responsibility is not for initial actions, but for training a veto for prohibited actions. For better understanding, imagine persons who were under education for controlling anger. Participants would be sensitive to impulsive behavior from confrontational situation. Then they would learn that connection between these confrontational circumstances and anger is useless. Actually, they would be conditional that when a confrontational situation happen, that emotional and impulsive reaction is ineffective. In real situation, in the first blush aggression might manifest but individuals are 
conditional to the idea that these reactions are vain and consequently unsocial behavior eliminates (Siegel \& Douard, 2011).

In addition, studies indicate those people who don't believe in free will, are more incline to show aggression, less empathy, less likely to conform themselves to pro-social behavior after violating social norms and to some extent poor work efficiency (Alquist, Ainsworth, \& Baumeister, 2013). Thus, this is critical to change conception of these individuals by exercising and educating them to believe in free will.

On a whole, education could result in prosaically behavior, inhabitation in maladaptive acts and curving aggression.

\section{NURSING}

A 15-year study on the impact of nursing suggests that home visiting during prenatal and early childhood by nurses could decrease strikingly maladaptive problems from children. For instance, $55 \%$ lesser arrests, $80 \%$ lesser criminal conviction and to lesser degree cigarette and alcohol use in comparison with kids who did not have nurse-visit (Liu, 2011).

A famous program which assesses criminal behavior is the Nurse-Family Partnership (NFP). This program indicated many positive aspects of child behavior. For example, it showed that nurse home visiting in the first two years after birth, decreased physical abuse and neglect significantly. Moreover, at fifteen, offspring of treatment mothers were dramatically lower in manifesting violent behaviors or other significant criminal acts in comparison with control groups (Rocque et al., 2012).

\section{GENE TREATMENT}

At the present time gene therapy is not a practice method. Since single-gene therapy did not prosper completely, thus, polygenic acts therapy would be a more complex approach. Another theory for eliminating maladaptive behaviors is pre-implantation diagnosis and selection. In brief, this policy could be used in individuals whose relatives have single-gene disorder. Scientists select those embryos without problem alleles from father and mother, and implant them into mother. However, problems such as determining relation between a gene and behavior make this approach farfetched (Baker, 2004).
DAMAGED PREFRONTAL CORTEX AND HEAD INJURY (LESION)

Prefrontal cortex (PFC), gives us a perspective of how others see and think about us, and make us to modify our behavior to take other's needs, concerns and expectations into account. Part of PFC's roles relates to social and adaptive behaviors as well as selfcontrol, impulsive and aggressive behavior (Schilling et al., 2011; de Almeida et al., 2005; Halász, Tóth, Kalló, Liposits, and Haller, 2006). For example, abnormalities of prefrontal cortex are found in violent offenders (Buss, 2006).

Evidences have manifested that a psychopath person has $22.3 \%$ decline in prefrontal gray matter (Glenn \& Raine, 2009). Moreover, minor head injuries result in violent acts and traumatic brain injuries in children is related to boosting behavioral problems and lack of emotional control (Liu, 2011). In addition, damage to PFC in infancy, is linked to lack of empathy in further years (Funk, 2005). One of the renowned events of damaged PFC is the railroad laborer, who had an accident and a rod entered in his skull at PFC, manifested more aggression, violent and weak judgment (LaPrairie et al., 2011).

\section{CONCLUSION}

There is a controversy about how should we aggravate or lessen the sentence of a convict who commits a crime because of biological and/or environmental problems. On the one hand, if we diminish the punishment, a person may commit a crime soon after being released. On the other hand, if we increase the penalty, it is against criminal law's aim since we are punishing a person who had impaired free will. But this problem could be addressed, if we treat the culprit or predict as well as prevent his/her next crime. For this reason, ways of prediction, prevention of crime and treatment of a lawbreaker should be studied. Generally, the authors of this article believe we should decrease the offender's sentence because of incomplete free will (whether it is because of biological or environmental problems). Moreover, he/she should pass a specific period of therapy instead of retribution to reduce the possibility of repeating an unlawful act. It is obvious that punishing these criminals is not effective and it may increase the gravity of disorders. In addition, these people do not have ordinary life and unfortunately they may have had a lot of hardships prior to committing the crime. Thus, they need more support than ordinary offenders. 
This article did not cover all aspects of biological and environmental problems and offered topics are just part of an ocean of human being's deficiencies. Authors strongly recommend other scholars to study over this subject, since the advancements of technology help us to solve many of the existing problems associated with individuals with predispositions to aggressive behavior and anti-social acts.

\section{REFERENCES}

Alimardani, Armin, 2012, "The Necessity of Identification of Semiresponsible Criminals Class and Proper Penal Policy against Them." M.A dissertation, department of law, Azad University of Damghan, Iran

Alimardani, Armin and Mohammad H. Abbaszadeh. 2014. "Penal Responsibility Concept Based on Determinism, Compatibility and Free Will Within New Researches", Rahyaft-e-Hoghoghi Journal, Iran, In press

Alper, Joseph S. 1998. "Genes, Free Will, and Criminal Responsibility". Social Science \& Medicine, 46(12): 15991611. http://dx.doi.org/10.1016/S0277-9536(97)10136-8

Alquist, Jessica L., Sarah E. Ainsworth, and Roy F. Baumeister. 2013. "Determined to Conform: Disbelief in Free Will Increases Conformity". Journal of Experimental Social Psychology, 49(1): 80-86. http://dx.doi.org/10.1016/j.jesp.2012.08.015

Baker, Catherine. 2004. Behavioral Genetics., Wash. DC: Am. Assoc. Adv. Sci

Barber, Nigel. 2008. "Evolutionary Social Science: A New Approach to Violent Crime". Aggression and Violent Behavior, 13(3), 237-250.

http://dx.doi.org/10.1016/j.avb.2008.04.002

Barber, Nigel. 2009. "From Steroids to Nation States: An Integrated Evolutionary Approach to Violent Crime". Aggression and Violent Behavior, 14(5): 415-422. http://dx.doi.org/10.1016/j.avb.2009.06.011

Barnes, J. C., and Brian B. Boutwell. 2012. "On the Relationship of Past to Future Involvement in Crime and Delinquency: A Behavior Genetic Analysis". Journal of Criminal Justice, 40(1): 94-102.

http://dx.doi.org/10.1016/j.jcrimjus.2011.12.003

Baxendale, Sarah, Donna Cross, and Robyn Johnston. 2012. "A Review of The Evidence on the Relationship Between Gender and Adolescents' Involvement in Violent Behavior." Aggression and Violent Behavior, 17(4): 297-310. http://dx.doi.org/10.1016/j.avb.2012.03.002

Beaver, Kevin M., John Paul Wright, Matt DeLisi, and Michael G. Vaughn. 2008. "Genetic Influences on the Stability of Low Self-control: Results from a Longitudinal Sample of Twins". Journal of Criminal Justice, 36(6): 478-485.

http://dx.doi.org/10.1016/j.jcrimjus.2008.09.006

Beaver, Kevin M., John Paul Wright, and Michael O. Maume. 2008. "The Effect of School Classroom Characteristics on Low Selfcontrol: A Multilevel Analysis." Journal of Criminal Justice, 36(2): 174-181. http://dx.doi.org/10.1016/j.jcrimjus.2008.02.007

Benton, David. 2007. "The Impact of Diet on Anti-Social, Violent and Criminal Behaviour." Neurosci Biobehav Rev, 31(5): 752-774. http://dx.doi.org/10.1016/j.neubiorev.2007.02.002

Bezdjian, Serena, Laura A. Baker, and Catherine Tuvblad. 2011. "Genetic and Environmental Influences on Impulsivity: A Meta-analysis of Twin, Family and Adoption Studies." Clinical Psychology Rev, 31(7): 1209-1223. http://dx.doi.org/10.1016/j.cpr.2011.07.005
Bifulco, A., Schimmenti, A., Jacobs, C., Bunn, A., \& Rusu, A. C. (2014). Risk Factors and Psychological Outcomes of Bullying Victimization: A Community-based Study. Child Indicators Research, 7(3), 633-648

http://dx.doi.org/10.1007/s12187-014-9236-8

Bjorklund, David F. 2006. "Mother Knows Best: Epigenetic Inheritance, Maternal Effects, and the Evolution of Human Intelligence." Developmental Review, 26(2), 213-242. http://dx.doi.org/10.1016/j.dr.2006.02.007

Blazei, Ryan W., William G. lacono, and Robert F. Krueger. 2006. "Intergenerational Transmission of Antisocial Behavior: How Do Kids Become Antisocial Aults?" Applied and Preventive Psychology, 11(4): 230-253. http://dx.doi.org/10.1016/j.appsy.2006.07.001

Bosse, Tibor, Charlotte Gerritsen, and Jan Treur. 2011. "On the Relation Between Cognitive and Biological Modelling of Criminal Behaviour". Computers in Human Behavior, 27(5): 1593-1611. http://dx.doi.org/10.1016/j.chb.2011.01.010

Buss, David M. 2006. The Murderer Next Door: Why the Mind Is Designed to Kill. Penguin.

Carnagey, Nicholas L., Craig A. Anderson, and Brad J. Bushman. 2007. "The Effect of Video Game Violence on Physiological Desensitization to Real-life Violence". Journal of Experimental Social Psychology, 43(3): 489-496. http://dx.doi.org/10.1016/j.jesp.2006.05.003

Chichinadze, Konstantin, Nodar Chichinadze, and Ann Lazarashvili. 2011. "Hormonal and Neurochemical Mechanisms of Aggression and a New Classification of Aggressive Behavior". Aggression and Violent Behavior, 16(6): 461-471. http://dx.doi.org/10.1016/j.avb.2011.03.002

Church II, Wesley T., Jeremiah W. Jaggers, and Julie K. Taylor 2012. "Neighborhood, Poverty, and Negative Behavior: An Examination of Differential Association and Social Control Theory". Children and Youth Services Review, 34(5): 10351041.

http://dx.doi.org/10.1016/j.childyouth.2012.02.005

Conrod, Patricia J., Natalie Castellanos-Ryan, and John Strang. 2010. "Brief, Personality-targeted Coping Skills Interventions and Survival as a Non-drug User Over a 2-year Period During Adolescence". Archives of General Psychiatry, 67(1): 85-93 http://dx.doi.org/10.1001/archgenpsychiatry.2009.173

de Almeida, Rosa MM, Pier Francesco Ferrari, Stefano Parmigiani, and Klaus A. Miczek. 2005. Escalated Aggressive Behavior: Dopamine, Serotonin and GABA. Eur J Pharmacol, 526(1-3): 51-64. http://dx.doi.org/10.1016/j.ejphar.2005.10.004

DeLisi, Matt. 2012. "Genetics: L'Enfant Terrible of Criminology". Journal of Criminal Justice, 40(6): 515-516. http://dx.doi.org/10.1016/j.jcrimjus.2012.08.002

DeLisi, Matt, Kevin M. Beaver, John Paul Wright, and Michael G. Vaughn. 2008. "The Etiology of Criminal Onset: The Enduring Salience of Nature and Nurture". Journal of Criminal Justice, 36(3): 217-223. http://dx.doi.org/10.1016/j.jcrimjus.2008.04.001

Eme, Robert. 2013. "MAOA and Male Antisocial Behavior: A Review". Aggression and Violent Behavior, 18(3): 395-398. http://dx.doi.org/10.1016/j.avb.2013.02.001

Farahany, Nita A., and James E. Coleman. 2006. "Genetics and Responsibility: to Know the Criminal from the Crime". Law and Contemporary Problems, 69: 115-164

Farisco, M., and C. Petrini. C. 2012. "The Impact of Neuroscience and Genetics on the Law: A Recent Italian Case". Neuroethics, 5(3): 317-319. http://dx.doi.org/10.1007/s12152-012-9152-x

Ferguson, Christopher J., and Kevin M. Beaver. 2009. "Natural Born Killers: The Genetic Origins of Extreme Violence". Aggression and Violent Behavior, 14(5): 286-294. http://dx.doi.org/10.1016/j.avb.2009.03.005 
Ferguson, Christopher J., and John Kilburn. 2009. "The Public Health Risks of Media Violence: A Meta-analytic Review". The Journal of pediatrics, 154(5): 759-763. http://dx.doi.org/10.1016/j.jpeds.2008.11.033

Fine, Cordelia, and Jeanette Kennett. 2004. "Mental Impairment, Moral Understanding and Criminal Responsibility: Psychopathy and the Purposes of Punishment". Int J Law Psychiatry, 27(5): 425-443. http://dx.doi.org/10.1016/j.ijlp.2004.06.005

Funk, Jeanne B. 2005. "Children's Exposure to Violent Video Games and Desensitization to Violence". Child Adolesc Psychiatr Clin N Am, 14(3): 387-404. http://dx.doi.org/10.1016/j.chc.2005.02.009

Garnefski, Nadia, and Sjoukje Okma. 1996. "Addiction-risk and Aggressive/Criminal Behaviour in Adolescence: Influence of Family, School and Peers". Journal of Adolescence Adolesc, 19(6): 503-512. http://dx.doi.org/10.1006/jado.1996.0049

Gleason, Erin D., Matthew J. Fuxjager, Temitayo O. Oyegbile, and Catherine A. Marler. 2009. Testosterone Release and Social Context: When it Occurs and Why. Front Neuroendocrinol, 30(4): 460-469. http://dx.doi.org/10.1016/j.yfrne.2009.04.009

Glenn, Andrea L., and Adrian Raine. 2009. "Psychopathy and Instrumental Aggression: Evolutionary, Neurobiological, and Legal Perspectives". International journal of law and psychiatry, 32(4), 253-258. http://dx.doi.org/10.1016/j.ijlp.2009.04.002

Hallett, Mark. 2007. "Volitional Control of Movement: the Physiology of Free Will". Clin Neurophysiol, 118(6): 1179-1192. http://dx.doi.org/10.1016/j.clinph.2007.03.019

Halász, József, Máté Tóth, Imre Kalló, Zsolt Liposits, and József Haller. 2006. "The Activation of Prefrontal Cortical Neurons in Aggression--A Double Labeling Study". Behavioural brain research, 175(1), 166-175 http://dx.doi.org/10.1016/j.bbr.2006.08.019

Haynes, Erin N., Aimin Chen, Patrick Ryan, Paul Succop, John Wright, and Kim N. Dietrich. 2011. "Exposure to Airborne Metals and Particulate Matter and Risk for Youth Adjudicated for Criminal Activity". Environ Res, 111(8): 1243-1248. http://dx.doi.org/10.1016/j.envres.2011.08.008

Henggeler, Scott W., Sonja K. Schoenwald, Charles M. Borduin, Melisa D. Rowland, and Phillippe B. Cunningham. 1998, Multisystemic Treatment of Antisocial Behavior in Children and Adolescents. Guilford Press.

Henggeler, Scott W., Sonja K. Schoenwald, Charles M. Borduin, Melisa D. Rowland, and Phillippe B. Cunningham. 2009. Multisystemic Therapy for Antisocial Behavior in Children and Adolescents. Guilford Press.

Humphreys, Janice, and Jacquelyn Campbell. 2011. Family Violence and Nursing Practice. Springer Publishing Company.

Kaye, David H. 2006. "Behavioral Genetics Research and Criminal DNA Databases". Law and Contemporary Problems, 69(1/2): 259-299.

Klevens, Joanne, José William Martínez, Brenda Le, Carlos Rojas, Adriana Duque, and Rafael Tovar. 2009. "Evaluation of Two Interventions to Reduce Aggressive and Antisocial Behavior in First and Second Graders in a Resource-poor Setting". International Journal of Educational Research, 48(5): 307319.

http://dx.doi.org/10.1016/j.ijer.2010.03.001

LaPrairie L. Jamie, Julia C. Schechter, Brittany A. Robinson and Patricia A. Brennan. 2011. "Perinatal Risk Factors in the Development of Aggression and Violence." Pp. 215-253, Vol 75, Advances in Genetics, edited by R. Huber, D. L. Bannasch and P. Brennan. In: Academic Press

Libet, Benjamin. 1985. "Unconscious Crebral Initiative and the Role of Conscious Will in Voluntary Action", Pp 529-539, Neurophysiology of Consciousness, Birkhäuser Boston.
Liu, Jianghong. 2011. "Early Health Risk Factors for Violence: Conceptualization, Review of the Evidence, and Implications". Aggressive Violent Behaviour, 16(1): 63-73. http://dx.doi.org/10.1016/j.avb.2010.12.003

Macions, John J, Ken Plummer. 2007, Sociology: A Global Introduction. Prentice Hall Europe :Granite Hill Publishers.

Manuck, Stephen B., Anna L. Marsland, Janine D. Flory, Adam Gorka, Robert E. Ferrell, and Ahmad R. Hariri. 2010. "Salivary Testosterone and a Trinucleotide (CAG) Length Polymorphism in the Androgen Receptor Gene Predict Amygdala Reactivity in Men". Psychoneuroendocrinology, 35(1): 94-104. http://dx.doi.org/10.1016/j.psyneuen.2009.04.013

Miller, Laurence. 2013. "Psychological Evaluations in the Criminal Justice System: Basic Principles and Best Practices". Aggression and Violent Behavior, 18(1): 83-91. http://dx.doi.org/10.1016/j.avb.2012.10.005

Montoya, Alonso, Bruce H. Price, Matthew Menear, and Martin Lepage. 2006. "Brain Imaging and Cognitive Dysfunctions in Huntington's Disease". Journal of Psychiatry and Neuroscience, 31(1): 21.

Morgado, Alice Murteira, and Maria da Luz Vale-Dias. 2013. "The Antisocial Phenomenon in Adolescence: What Is Literature Telling us?" Aggression and Violent Behavior. 18(4): 436-443 http://dx.doi.org/10.1016/j.avb.2013.05.004

Morse, Stephen J. 2011. "Genetics and Criminal Responsibility". Trends in cognitive sciences, 15(9): 378-380. http://dx.doi.org/10.1016/j.tics.2011.06.009

Morse, Stephen J., and Morris B. Hoffman. 2007. "The Uneasy Entente Between Legal Insanity and Mens Rea: Beyond Clark v. Arizona". The Journal of Criminal Law and Criminology, 1071-1149.

Myers, Richard H. 2004. "Huntington's Disease Genetics". NeuroRx, 1(2): 255-262. http://dx.doi.org/10.1602/neurorx.1.2.255

National Center for Microscopy and Imaging Research. Instrumental in Huntington's Disease Breakthrough. 2011. Retrieved July20, 2013 (http://ncmir.ucsd.edu/research/highlights/ 2011_huntingtons.shtm)

Nevin, Rick. 2007. "Understanding International Crime Trends: the Legacy of Preschool Lead Exposure". Environ Res, 104(3): 315-336. http://dx.doi.org/10.1016/j.envres.2007.02.008

Pagani, Linda S. 2013. "Environmental Tobacco Smoke Exposure and Brain Development: The Case of Attention Deficit/Hyperactivity Disorder". Neurosci Biobehav Review.

Poduska, Jeanne M., Sheppard G. Kellam, Wei Wang, C. Hendricks Brown, Nicholas S. lalongo, and Peter Toyinbo. 2008. "Impact of the Good Behavior Game, a Universal Classroombased Behavior Intervention, on Young Adult Service Use for Problems with Emotions, Behavior, or Drugs or Alcohol". Drug Alcohol Depend, 95 Suppl 1: S29-44. http://dx.doi.org/10.1016/j.drugalcdep.2007.10.009

Rocque, Michael, Brandon C. Welsh, and Adrian Raine. 2012. "Biosocial Criminology and Modern Crime Prevention". Journal of Criminal Justice, 40(4): 306-312. http://dx.doi.org/10.1016/j.jcrimjus.2012.05.003

Schraft, C. V., Kosson, D. S., \& McBride, C. K. (2013). Exposure to Violence within Home and Community Environments and Psychopathic Tendencies in Detained Adolescents. Criminal Justice and Behavior, 40(9), 1027-1043 http://dx.doi.org/10.1177/0093854813486887

Schilling, Catrina M., Anthony Walsh, and Ilhong Yun. 2011. "ADHD and Criminality: A Primer on the Genetic, Neurobiological, Evolutionary, and Treatment Literature for Criminologists". Journal of Criminal Justice, 39(1): 3-11. http://dx.doi.org/10.1016/j.jcrimjus.2010.11.001

Schimmenti, A., Passanisi, A., Pace, U., Manzella, S., Di Carlo, G., \& Caretti, V. 2014. The Relationship Between Attachment and 
Psychopathy: A Study with a Sample of Violent Offenders. Current Psychology, 33(3), 256-270.

http://dx.doi.org/10.1007/s12144-014-9211-z

Shepard, Kathryn N., Vasiliki Michopoulos, Donna J. Toufexis, and Mark E. Wilson. 2009. "Genetic, Epigenetic and Environmental Impact on Sex Differences in Social Behavior". Physiol Behav, 97(2), 157-170. http://dx.doi.org/10.1016/j.physbeh.2009.02.016

Siegel, Allan, and John Douard. 2011."Who's Flying the Plane: Serotonin Levels, Aggression and Free Will". Int J Law Psychiatry, 34(1): 20-29. http://dx.doi.org/10.1016/j.jilp.2010.11.004

Steinert, Tilman, and Richard Whittington. 2013. "A Bio-psycho-social Model of Violence Related to Mental Health Problems". Int J Law Psychiatry, 36(2): 168-175. http://dx.doi.org/10.1016/.ijilp.2013.01.009

Susman, Elizabeth J. 2006. "Psychobiology of Persistent Antisocial Behavior: Stress, Early Vulnerabilities and the Attenuation Hypothesis". Neurosci Biobehav Rev, 30(3): 376-389. http://dx.doi.org/10.1016/j.neubiorev.2005.08.002

Turkheimer, Eric. 2000. "Three Laws of Behavior Genetics and What They Mean". Current Directions in Psychological Science, 9(5): 160-164. http://dx.doi.org/10.1111/1467-8721.00084

Turner, Michael G., Crista M. Livecchi, Kevin M. Beaver, and Jeb Booth. 2011. "Moving Beyond the Socialization Hypothesis: The Effects of Maternal Smoking During Pregnancy on the Development of Self-control". Journal of Criminal Justice, 39(2): 120-127. http://dx.doi.org/10.1016/j.jcrimjus.2010.12.004

Umukoro, Solomon, Aderemi C. Aladeokin, and Anthony T. Eduviere. 2013. "Aggressive Behavior: A Comprehensive Review of Its Neurochemical Mechanisms and Management". Aggression and Violent Behavior, 18(2): 195-203. http://dx.doi.org/10.1016/j.avb.2012.11.002

Vaughn, Michael G., Matt DeLisi, Kevin M. Beaver, and John Paul Wright. 2009. "DAT1 and 5HTT are Associated with
Pathological Criminal Behavior in a Nationally Representative Sample of Youth". Criminal Justice and Behavior, 36(11): 1113-1124 http://dx.doi.org/10.1177/0093854809342839

Victoroff, Jeff. 2009. "Aggression, Science, and Law: The Origins Framework. Introduction". International journal of law and psychiatry, 32(4): 189-197. http://dx.doi.org/10.1016/j.ijlp.2009.04.009

Vucetic, Z., Totoki, K., Schoch, H., Whitaker, K. W., Hill-Smith, T. Lucki, I., \& Reyes, T. M. 2010. Early Life Protein Restriction Alters Dopamine Circuitry. Neuroscience, 168(2): 359-370. http://dx.doi.org/10.1016/j.neuroscience.2010.04.010

Walsh, William J., Laura B. Glab, and Mary L. Haakenson. 2004 "Reduced Violent Behavior Following Biochemical Therapy". Physiol Behav, 82(5): 835-839. http://dx.doi.org/10.1016/j.physbeh.2004.06.023

World Health Organization. Child Maltreatment. (N.d.). Retrieved July30. 2013, from (http://www.who.int/topics/child_ abuse/en/)

Widom, Cathy Spatz, and Linda M. Brzustowicz. 2006. "MAOA and the "Cycle of Violence:" Childhood Abuse and Neglect, MAOA Genotype, and Risk for Violent and Antisocial Behavior". Biological psychiatry, 60(7): 684-689. http://dx.doi.org/10.1016/j.biopsych.2006.03.039

Wikipedia. Dopamine. 2013. Retrieved August 25. 2013 from (http://en.wikipedia.org/wiki/Dopamine)

Wu, Tong, and J. C. Barnes. 2013. "Two Dopamine Receptor Genes (DRD2 and DRD4) Predict Psychopathic Personality Traits in a Sample of American Adults". Journal of Criminal Justice, 41(3): 188-195 http://dx.doi.org/10.1016/j.jcrimjus.2013.02.001

Yildirim, Bariş O., and Jan JL Derksen. 2012. "A Review on the Relationship Between Testosterone and Life-course Persistent Antisocial Behavior". Psychiatry research. 200(23): 984-1010. http://dx.doi.org/10.1016/j.psychres.2012.07.044

(c) 2014 Alimardani et al.; Licensee Lifescience Global.

This is an open access article licensed under the terms of the Creative Commons Attribution Non-Commercial License (http://creativecommons.org/licenses/by-nc/3.0/) which permits unrestricted, non-commercial use, distribution and reproduction in any medium, provided the work is properly cited. 